\title{
Differential Regulation of Mitogen-Activated Protein Kinases ERK1/2 and ERK5 by Neurotrophins, Neuronal Activity, and cAMP in Neurons
}

\author{
Jane E. Cavanaugh, ${ }^{1,2}$ James Ham, ${ }^{1}$ Michal Hetman, ${ }^{1,2}$ Steve Poser, ${ }^{2}$ Chen Yan, ${ }^{3}$ and Zhengui Xia ${ }^{1,2}$ \\ Departments of ${ }^{1}$ Environmental Health and ${ }^{2}$ Pharmacology, University of Washington, Seattle, Washington 98195-7234, \\ and ${ }^{3}$ Cardiology Unit, University of Rochester, Rochester, New York 14642
}

\begin{abstract}
Activation of the extracellular signal-regulated kinase 1 (ERK1) and ERK2 by neurotrophins, neuronal activity, or cAMP has been strongly implicated in differentiation, survival, and adaptive responses of neurons during development and in the adult brain. Recently, a new member of the mitogen-activated protein (MAP) kinase family, ERK5, was discovered. Like ERK1 and ERK2, ERK5 is expressed in neurons, and ERK5 stimulation by epidermal growth factor is blocked by the MAP kinase/ERK kinase 1 (MEK1) inhibitors PD98059 and U0126. This suggests the interesting possibility that some of the functions attributed to ERK1/2 may be mediated by ERK5. However, the regulatory properties of ERK5 in primary cultured neurons have not been reported. Here we examined the regulation of ERK5 signaling in primary cultured cortical neurons. Our data demonstrate that, similar to ERK1/2, ERK5 is activated by neurotrophins including brain-derived neurotrophic factor (BDNF), neurotrophin-3 (NT3 ), and NT-4. BDNF stimulation of ERK5 required the activity of MEK5. Surprisingly, ERK5 was not stimulated by cAMP or
\end{abstract}

Activation of extracellular signal-regulated kinase 1 (ERK1) and ERK2 is important for several neuronal functions that are regulated by neurotrophins and neuronal activity. This includes neuronal differentiation and survival during development, as well as survival and adaptive responses of mature neurons including long-term potentiation (LTP) and memory formation. For example, stimulation of the ERK1/2-signaling pathway promotes neuronal survival (Xia et al., 1995; Bonni et al., 1999; Hetman et al., 1999) and is important for LTP as well as memory formation in vertebrates (English and Sweatt, 1997; Atkins et al., 1998; Impey et al., 1998a, 1999). The $\mathrm{Ca}^{2+}$ response element-binding protein (CREB)/CRE transcriptional pathway is a major regulatory target of ERK1/2 signaling and may be pivotal for plasticity and neuronal survival mediated by ERK1/2 (Montminy and Bilezikjian, 1987; Impey et al., 1998a,b; Bonni et al., 1999; Riccio et al., 1999). The transcription factor Elk1 may be another nuclear

\footnotetext{
Received June 7, 2000; revised Sept. 26, 2000; accepted Nov. 2, 2000.

This work was supported by the National Institute of Neurological Disorders and Stroke Grant NS37359 and the Burroughs Wellcome Fund for New Investigator Award in Toxicology Grant APP\#3010 (Z.X.). J.E.C. was supported by the National Institutes of Health Postdoctoral Training Grant Genetic Approaches to Aging (2 T32 AG00057-21). We thank Dr. J. D. Lee for providing anti-ERK5 antibody and expression vectors for ERK5, MEK5, and GST-ERK5 (M). We thank Dr. J. Silvio Gutkind for GST-MEF2C. We thank Dr. J. Han for providing the Gal4-MEF2C and Flag-tagged wild-type ERK2 plasmids.

Correspondence should be addressed to Dr. Zhengui Xia, Department of Environmental Health, Box 357234, University of Washington, HSB, Room F561C, Seattle, WA 98195. E-mail: zxia@u.washington.edu.

Copyright (C) 2001 Society for Neuroscience 0270-6474/01/210434-10\$15.00/0
}

neuronal activity induced by glutamate or membrane depolarization. In contrast to ERK1/2, ERK5 strongly activated the transcriptional activity of myocyte enhancer factor 2C (MEF2C) in pheochromocytoma 12 (PC12) cells and was required for neurotrophin stimulation of MEF2C transcription in both PC12 cells and cortical neurons. Furthermore, ERK1/2, but not ERK5, induced transcription from Elk1 and the cAMP/ $\mathrm{Ca}^{2+}$ response element in PC12 cells. Our data suggest that mechanisms for regulation of ERK5 and downstream transcriptional pathways regulated by ERK5 are distinct from those of ERK1/2 in neurons. Furthermore, ERK5 is the first MAP kinase identified whose activity is stimulated by neurotrophins but not by neuronal activity.

Key words: signal transduction; CNS; cortical neurons; neurons; MAP kinase; ERK1/2; ERK5; BMK1; CREB; CRE; MEF2C; $B D N F ;$ glutamate; membrane depolarization; neuronal activity; neurotrophin; $c A M P$

target of ERK1/2 important for neuronal plasticity (Berman et al., 1998). Elk1 is directly phosphorylated and activated by ERK1/2 and plays an important role in glutamate-induced gene expression in neurons (Gille et al., 1992; Xia et al., 1996; Sgambato et al., 1998).

ERK1/2 activity is regulated by the cAMP-signaling pathway. Although cAMP inhibits ERK1/2 in non-neuronal cells (Burgering et al., 1993; Graves et al., 1993), it activates ERK1/2 in pheochromocytoma 12 (PC12) cells and neurons (Erhardt et al., 1995; Martin et al., 1997; Vossler et al., 1997; Wei et al., 1998). cAMP is required for ERK1/2 activation of gene expression (Wei et al., 1998; Yao et al., 1998), and stimulation of ERK1/2 by cAMP and $\mathrm{Ca}^{2+}$ is critical for long-lasting LTP (English and Sweatt, 1996; Impey et al., 1998b).

ERK5 or big mitogen-activated protein (MAP) kinase 1 is the newest member of the MAP kinase family (Lee et al., 1995; Z hou et al., 1995). Upstream-signaling proteins of the ERK5 pathway include MEK5, MEKK3, and Cot (English et al., 1995; Zhou et al., 1995; Chao et al., 1999; Chiariello et al., 2000). Although ERK5 contains a TEY dual phosphorylation motif similar to that of ERK1/2, a large $\mathrm{C}$ terminal and a unique loop-12 sequence distinguish it from ERK1/2 and other MAP kinase family members. ERK5 is activated by serum, epidermal growth factor (EGF), nerve growth factor (NGF), and G-protein-coupled receptors and weakly by phorbol esters (Kato et al., 1997, 1998; English et al., 1998; Chao et al., 1999; Kamakura et al., 1999; Marinissen et al., 1999). ERK5 contributes to EGF-induced cell 
proliferation and cell cycle progression (Kato et al., 1998) as well as Ras-dependent cellular transformation (English et al., 1999).

The MEK1/2 inhibitors PD98059, SL327, and U0126 have been extensively used to implicate ERK1/2 in neuroplasticity (Impey et al., 1999) and neuronal survival (Villalba and Journot, 1997; MeyerFranke et al., 1998; Skaper et al., 1998; Anderson and Tolkovsky, 1999; Singer et al., 1999; Bi et al., 2000). Interestingly, ERK5 activation by EGF in COS7 cells is also blocked by these inhibitors (Kamakura et al., 1999), suggesting that the ERK5 pathway may also regulate cellular processes credited previously to ERK1/2. However, the regulatory properties of ERK5 and the downstream transcriptional events involved in the ERK5 signaling in neurons have not been reported. Consequently, it is crucial to define ERK5-signaling mechanisms in neurons.

In this study, we examined the regulation of ERK5 signaling in primary cultures of cortical neurons and in PC12 cells. We measured ERK5 activity by two well established methods: ERK5 autophosphorylation (Abe et al., 1997; Yan et al., 1999) and reduced electrophoretic mobility (phosphorylation shift) (Kato et al., 1997, 1998). We report that ERK5 is activated by neurotrophins but not by neuronal activity or cAMP in cortical neurons. Furthermore, ERK1/2 and ERK5 activate distinct transcription pathways in PC12 cells and cortical neurons. These data suggest that ERK5 and ERK1/2 are differentially regulated in cortical neurons.

\section{MATERIALS AND METHODS}

Materials. The following plasmids have been described: pON260 (Cherrington and Mocarski, 1989), the dominant-negative and constitutively active MEK1 (Mansour et al., 1994), the pGEX-GST-ERK5 [C-terminal 100 amino acids (aa)] (Yan et al., 1999), and CRE $(\alpha 168)$ luciferase (Matthews et al., 1994). The following materials were obtained from Dr. J. D. Lee at Scripps Institute, La Jolla, CA (Kato et al., 1997): the Flag-tagged wild-type ERK5 expression vector, the hemagglutinin (HA)-tagged dominant-negative and constitutively active MEK5 expression vectors, the pGEX-GST-ERK5 (M; short form), and the polyclonal anti-peptide

body against the C-terminal sequence of ERK5 (EGHGMNPADIESLQREIQMDSPML). The polyclonal anti-phospho-ERK1/2 antibody (anti-ACTIVE mitogen-activated protein kinase) was purchased from Promega (Madison, WI).

Cell cultures. Primary cortical neurons were prepared from newborn Sprague Dawley rats as described (Hetman et al., 1999, 2000). Briefly, dissociated cortical neurons were plated in $60 \mathrm{~mm}$ culture dishes for biochemistry experiments or in $35 \mathrm{~mm}$ dishes for transfection experiments at a density of $4 \times 10^{6}$ cells $/ 60 \mathrm{~mm}$ dish or $2 \times 10^{6}$ cells $/ 35 \mathrm{~mm}$ dish, respectively; cultured in basal medium Eagle (BME) supplemented with $10 \%$ heat-inactivated bovine calf serum (BCS), $35 \mathrm{~mm}$ glucose, 1 $\mathrm{mM}$ L-glutamine, $100 \mathrm{U} / \mathrm{ml}$ penicillin, and $0.1 \mathrm{mg} / \mathrm{ml}$ streptomycin; and maintained in a humidified incubator with $5 \% \mathrm{CO}_{2}$ at $37^{\circ} \mathrm{C}$. Plates and glass coverslips were coated with poly-D-lysine and laminin. Cytosine- $\beta$ D-arabinof uranoside (Ara-C; $2.5 \mu \mathrm{M}$; Sigma, St. Louis, MO) was added to cultures on the second day after seeding (DIV2) to inhibit the proliferation of non-neuronal cells. Previous studies demonstrated that $>90 \%$ of the cells in this culture preparation are neurons (Hetman et al., 1999). Cortical neurons were cultured for 6 d (DIV6) before drug treatment. PC12 cells were maintained in DMEM (Life Technologies, Gaithersburg, MD) supplemented with $10 \%$ BCS, $5 \%$ fetal bovine serum (Life Technologies), $100 \mathrm{U} / \mathrm{ml}$ penicillin, and $0.1 \mathrm{mg} / \mathrm{ml}$ streptomycin.

Transient transfection of primary cortical neurons for kinase assays. Cortical neurons $\left(2 \times 10^{6}\right.$ cells $/ 35 \mathrm{~mm}$ dish $)$ were transiently transfected at DIV3 using a calcium phosphate coprecipitation protocol as described (Xia et al., 1996; Hetman et al., 1999). Briefly, the DNA-calcium phosphate precipitates were prepared by mixing 1 vol of DNA in $250 \mathrm{~mm}$ $\mathrm{CaCl}_{2}$ with an equal volume of $2 \times$ HEPES-buffered saline (HBS; 274 $\mathrm{mm} \mathrm{NaCl}, 10 \mathrm{~mm} \mathrm{KCl}, 1.4 \mathrm{~mm} \mathrm{Na} \mathrm{HPO}_{4}, 15 \mathrm{~mm}$-glucose, and $42 \mathrm{~mm}$ HEPES, $\mathrm{pH}$ 7.07). The precipitates were allowed to form for $25-30 \mathrm{~min}$ at room temperature before addition to the cultures. The conditioned culture media were removed and saved. Cells were washed three times with $\mathrm{BME}$, and $1.5 \mathrm{ml}$ of transfection media was added to each $35 \mathrm{~mm}$ dish. The transfection media consist of BME supplemented with $1 \mathrm{~mm}$ sodium kynurenate, $10 \mathrm{~mm} \mathrm{MgCl}_{2}$, and $5 \mathrm{~mm}$ HEPES. The $\mathrm{pH}$ of the transfection media was kept high by incubating $\mathrm{BME}$ in a dish at $37^{\circ} \mathrm{C}$ and $0 \% \mathrm{CO}_{2}$ for $30 \mathrm{~min}$ to "degas." Sixty microliters of the DNAcalcium phosphate precipitates were added dropwise to each $35 \mathrm{~mm}$ dish and mixed gently. Plates were incubated at room temperature and ambient air for $5 \mathrm{~min}$ and then in a humidified incubator with $5 \% \mathrm{CO}_{2}$ at $37^{\circ} \mathrm{C}$ for $35-45 \mathrm{~min}$. The incubation was stopped $20-25 \mathrm{~min}$ after the layer of precipitate formed on the plates by "shocking" the cells for $2 \mathrm{~min}$ with $1 \times \mathrm{HBS}, 1 \mathrm{~mm}$ sodium kynurenate, and $10 \mathrm{~mm} \mathrm{MgCl}_{2}$ in $5 \mathrm{~mm}$ HEPES, $\mathrm{pH} 7.5$, and $5 \%$ glycerol. Cells were then washed three times with $2 \mathrm{ml}$ of BME. The saved conditioned media were added back to each plate, and cells were returned to the $5 \% \mathrm{CO}_{2}$ incubator at $37^{\circ} \mathrm{C}$ for $48 \mathrm{hr}$ before treatment or harvesting.

Drug treatment. Drug treatment was performed at DIV6 for cortical neurons. Forskolin was dissolved in ethanol. Ethanol was used as vehicle control for forskolin treatment. K252a was dissolved in water and added 30 min before BDNF stimulation. Doses and times of drug treatment are described in detail in the figure legends.

Generation of a polyclonal anti-ERK5 antibody. We made a polyclonal antibody against ERK5 by immunizing rabbits (Cocalico Biologicals, Reamstown, PA) with the GST-ERK5 (C-terminal 100 aa) fusion protein. This anti-ERK5 antibody was used in the ERK5 autophosphorylation kinase assay. The specificity of this antibody was confirmed by showing that ERK5 autophosphorylation was not seen when the antiERK5 antibody was preincubated with the GST-ERK5 fusion protein used to generate the antibody or when preimmune sera were used for immune precipitation of ERK5 (data not shown).

Kinase assays. Cell lysates were prepared as described previously (Dérijard et al., 1995; Xia et al., 1995), and protein concentrations were assayed by the Bradford method. Equal amounts of protein extracts (300 $\mu \mathrm{g})$ were used for each kinase assay. To measure endogenous ERK5 activity, cell lysates were incubated at $4^{\circ} \mathrm{C}$ for $2.5 \mathrm{hr}$ with $6 \mu \mathrm{l}$ of the antisera against the GST-ERK5 C-terminal 100 aa fusion protein that we generated. Protein A-Sepharose beads $(60 \mu \mathrm{l})$ were then added, and the mixture was incubated at $4^{\circ} \mathrm{C}$ for an additional hour. The endogenous ERK5 activity in the immune precipitates was then quantitated by an autophosphorylation assay as described (Abe et al., 1997; Yan et al., 1999).

To measure the activity of transfected ERK5 or ERK2, cell lysates $(200-300 \mu \mathrm{g})$ were incubated with an anti-Flag antibody prebound to a slurry of $80 \%$ protein G-Sepharose and $20 \%$ protein A-Sepharose. The activity of transfected ERK5 or ERK2 in the immune precipitates was quantitated by a kinase assay using recombinant GST-MEF2C $(10 \mu \mathrm{g})$ or MBP $(2.5 \mu \mathrm{g})$ as the substrate, respectively (Xia et al., 1995; Kato et al., 1997, 1998; Hetman et al., 1999).

To measure endogenous MEK5 activity, cell lysates $(300 \mu \mathrm{g})$ were incubated at $4^{\circ} \mathrm{C}$ for $3 \mathrm{hr}$ with an anti-MEK5 antibody (N-19; Santa Cruz Biotechnology, Santa Cruz, CA) prebound to protein G-Sepharose beads. The MEK5 activity in the immune precipitates was quantitated by a kinase assay using a recombinant GST-ERK5(M) as the substrate (Kato et al., 1997, 1998; Kamakura et al., 1999; Marinissen et al., 1999). Quantitation of kinase activity was achieved by PhosphorImager analysis (Molecular Dynamics, Sunnyvale, CA) or by using the ImageQuant program after scanning the autoradiographic images.

Western analysis. Western blot analysis of ERK5 and anti-phosphoERK1/2 was performed as described (Kato et al., 1997; Chao et al., 1999; Hetman et al., 1999). The polyclonal anti-ERK5 peptide antibody used for Western analysis was kindly provided by Dr. J. D. Lee and was used at a dilution of 1:5000.

Reporter gene assays. PC12 cells were transfected using Transfast (Promega) as described by the manufacturer. Briefly, $1 \times 10^{5}$ cells were plated onto each well of a 24 -well plate coated with poly-D-lysine (Sigma). One day later, cells were transfected with a CRE-luciferase reporter gene $(1.2 \mu \mathrm{g} / 3$ wells) or a Gal4-luciferase reporter gene $(0.2 \mu \mathrm{g} / 3$ wells) together with various expression vectors for Gal4 fusion proteins $(0.4 \mu \mathrm{g} / 3$ wells). The EF1a.LacZ DNA (Invitrogen, San Diego, CA) was added at $0.125 \mu \mathrm{g} / 3$ wells for normalization of transfection efficiency. Cortical neurons were transfected using LipofectAMINE 2000 (Life Technologies) (Impey et al., 1996; Poser et al., 2000). Briefly, $0.5 \times 10^{6}$ cells were plated onto each well of a 24-well plate coated with poly-Dlysine (Research Collaborative). At DIV4-DIV5, neurons were cotransfected with the Gal4-luciferase reporter gene (1.4 $\mu \mathrm{g} / 4$ wells), Gal4MEF2C fusion protein $(0.9 \mu \mathrm{g} /$ well $)$, and EF1a.LacZ DNA $(0.55 \mu \mathrm{g} / 4$ 
wells). Where indicated, PC12 cells and cortical neurons were also cotransfected with various expression vectors for the ERK5- and ERK1/ 2 -signaling pathways. For PC12 cells, cells were serum starved at $1 \mathrm{~d}$ after transfection for $24 \mathrm{hr}$ and then treated with NGF $(50 \mathrm{ng} / \mathrm{ml})$ for $6 \mathrm{hr}$ when indicated. For cortical neurons, cells were treated at $2 \mathrm{~d}$ after transfection with $10 \mathrm{ng} / \mathrm{ml} \mathrm{BDNF}$ or $55 \mathrm{~mm} \mathrm{KCl}$ for $6 \mathrm{hr}$ when indicated. Cell lysates were prepared, and the activities of luciferase or $\beta$-galactosidase were measured as described (Impey et al., 1996). The reporter gene luciferase activity was normalized to $\beta$-galactosidase activity and expressed as the fold induction relative to control.

\section{RESULTS}

\section{ERK5 is activated by neurotrophins in primary cortical neurons}

ERK1/2 is activated by growth factors and neurotrophins in several cell types including neurons (Ahn et al., 1992; Castellino and Chao, 1996; Segal and Greenberg, 1996). Similarly, ERK5 is activated by EGF and NGF in PC12 and non-neuronal cells (Kato
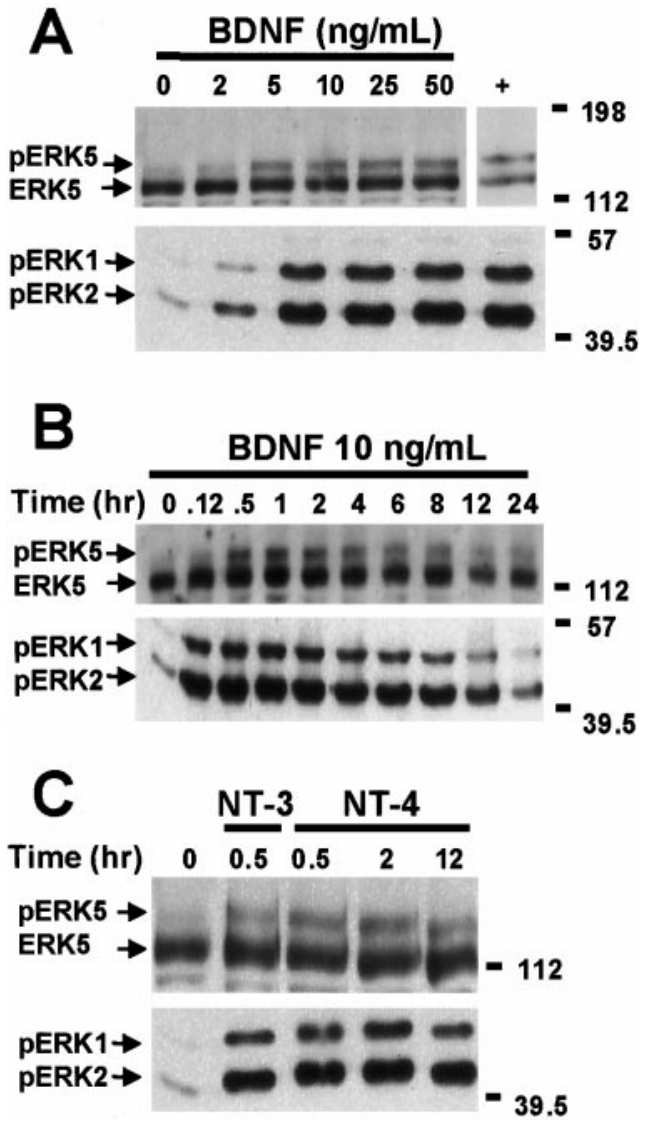

Figure 1. Neurotrophins induce ERK5 and ERK1/2 phosphorylation in cortical neurons. $A$, Dose-response relationship of BDNF stimulation of ERK5 and ERK1/2 phosphorylation is shown. At DIV5, cortical neurons were treated with $0,2,5,10,25$, or $50 \mathrm{ng} / \mathrm{ml}$ BDNF for $1 \mathrm{hr}$. Cell lysates from human embryonic kidney 293 cells transiently transfected with a constitutively active MEK5 and a wild-type ERK5 were used as a positive control $(+)$ for the ERK5 phosphorylation shift. $B$, Kinetics of BDNF stimulation of ERK5 and ERK1/2 phosphorylation is shown. At DIV5, cortical neurons were treated with $10 \mathrm{ng} / \mathrm{ml}$ BDNF for the indicated times. $C$, NT-3 and NT-4 also induce ERK5 and ERK1/2 phosphorylation. At DIV5, cortical neurons were treated with $10 \mathrm{ng} / \mathrm{ml} \mathrm{NT}-3$ or NT-4 for $0.5,2$, or $12 \mathrm{hr}$. Cell lysates were prepared, and $20 \mu \mathrm{g}$ of total protein was submitted to Western analysis using antibodies recognizing ERK5 (Abe et al., 1996) or phosphorylated ( $p$ ) ERK1/2. Phosphorylation of ERK5 was observed as a shift in ERK5 mobility, indicative of ERK5 activation. The anti-phospho-ERK1/2 antibody recognizes the phosphorylated and activated ERK1/2, indicative of ERK1/2 activation. Data are representative of four $(A, B)$ or three $(C)$ independent experiments. The positions of molecular weight markers are indicated on the right of the figures. et al., 1998; Kamakura et al., 1999). However, the regulation of ERK5 by neurotrophins in primary cultured neurons derived from CNS has not been reported. Therefore, we examined whether ERK5 is stimulated by various physiological stimuli in cortical neurons and compared the regulation of ERK5 with that of ERK1/2. Cortical neurons were treated with various concentrations $(0-50 \mathrm{ng} / \mathrm{ml})$ of BDNF for $1 \mathrm{hr}$, and the cell lysates were analyzed by Western analysis using antibodies against ERK5 or phospho-ERK1/2 (Fig. 1A). BDNF treatment, at concentrations as low as $5 \mathrm{ng} / \mathrm{ml}$, caused a reduced electrophoretic mobility (phosphorylation shift) of ERK5, indicative of ERK5 activation (Kato et al., 1997, 1998). The phosphorylation shift of ERK5 was maximal at $10 \mathrm{ng} / \mathrm{ml} \mathrm{BDNF}$, a concentration of BDNF used in subsequent studies. ERK1/2 activation was measured by Western analysis using the anti-phospho-ERK1/2 antibody that recognizes phosphorylated and activated ERK1/2. As reported previously (Marsh et al., 1993; Hetman et al., 1999), BDNF activated ERK1/2 in cortical neurons, and the dose-response curves for activation of ERK5 and ERK1/2 were similar.

To determine the kinetics of ERK5 activation, cortical neurons were treated with $10 \mathrm{ng} / \mathrm{ml}$ BDNF for various times. Like ERK1/2 activation, ERK5 activation was prolonged and sustained for up to $24 \mathrm{hr}$ after BDNF treatment (Fig. 1B). However, the peak activation of ERK5 was slower than that of ERK1/2. Although ERK5 activation was detectable at $5 \mathrm{~min}$, it did not reach a maximum until 1-2 hr after BDNF treatment. The slow kinetics of ERK5 activation was also confirmed by the autophosphorylation assay (e.g., see Fig. 3). In contrast, ERK1/2 was maximally activated by BDNF at 30 min under the same conditions using the same cultured neuron preparations. In addition to BDNF, other neurotrophins, including neurotrophin-3 (NT-3), NT-4, and NGF, also activate ERK1/2 (Castellino and Chao, 1996; Segal and Greenberg, 1996). Similarly, ERK5 was activated by NT-3 or NT-4 treatment of cortical neurons (Fig. 1C). In agreement with other reports (Kamakura et al., 1999), NGF treatment of PC12 cells activated ERK5 (data not shown).

To determine whether BDNF activation of ERK5 requires TrkB tyrosine kinase activity, cortical neurons were treated with $\mathrm{K} 252 \mathrm{a}$, an inhibitor of receptor tyrosine kinases. Like ERK1/2, ERK5 activation was inhibited by K252a (Fig. 2), suggesting that inhibition of receptor tyrosine kinase prevents BDNF stimulation of both ERK5 and ERK1/2.

To confirm ERK5 activation by BDNF, ERK5 activity was quantitated using an ERK5 autophosphorylation assay after immune precipitation of ERK5. This alternative assay was used because activation of ERK5 leads to increased ERK5 autophosphorylation (Abe et al., 1997; Yan et al., 1999). BDNF stimula-

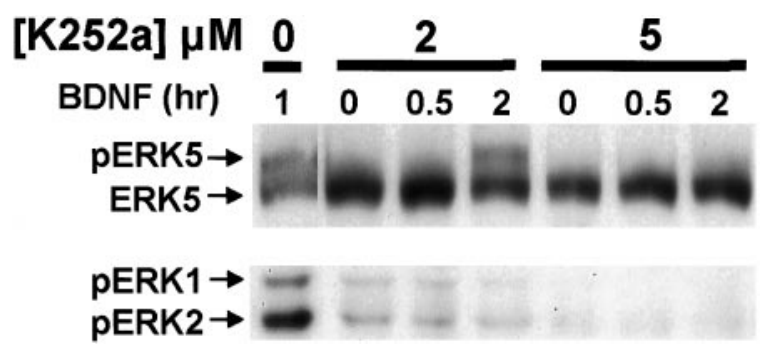

Figure 2. BDNF stimulation of ERK5 phosphorylation requires receptor tyrosine kinase activity. Cortical neurons (DIV5-DIV6) were pretreated with 0,2 , or $5 \mu \mathrm{M} \mathrm{K} 252 \mathrm{a}$ for $30 \mathrm{~min}$ and then stimulated with $10 \mathrm{ng} / \mathrm{ml}$ BDNF for $0.5,1$, or $2 \mathrm{hr}$ as indicated. Phosphorylation $(p)$ of ERK5 and ERK1/2 was measured by Western analysis as described in Figure 1. Similar results were obtained in two independent experiments. 


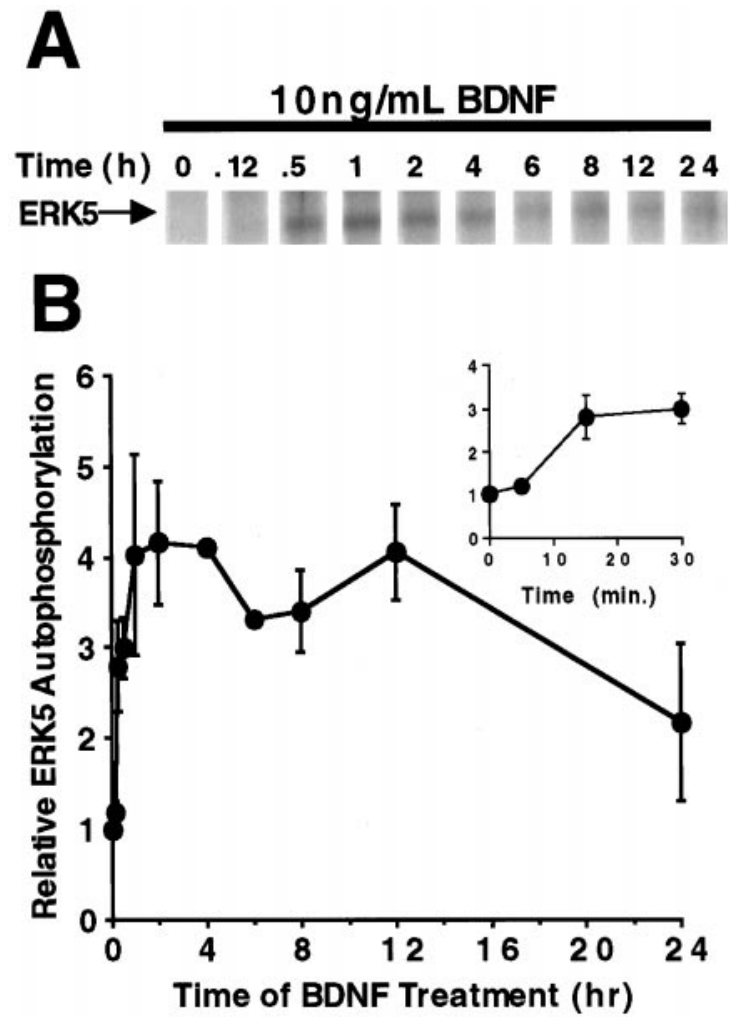

Figure 3. BDNF activates ERK5 in cortical neurons. Cortical neurons (DIV5-DIV6) were treated with $10 \mathrm{ng} / \mathrm{ml} \mathrm{BDNF}$ for various times. Three hundred micrograms of total protein were used to measure ERK5 activity by the autophosphorylation assay. $A, \mathrm{~A}$ representative autoradiograph of the ERK5 autophosphorylation kinase assay. $B$, Quantitation of ERK5 autophosphorylation. Inset, A more detailed profile of ERK5 activation at early time points. Data are the average of five to seven experiments. Error bars represent SEM.

tion of cortical neurons increased ERK5 autophosphorylation fourfold, and the kinetics of activation was comparable with that measured using the phosphorylation shift assay (Fig. 3). Together, the phosphorylation shift and autophosphorylation data indicate that neurotrophins activate both ERK5 and ERK1/2 in cortical neurons.

\section{MEK5 is activated by BDNF and is required for BDNF stimulation of ERK5}

MEK5 is an upstream kinase that phosphorylates and activates ERK5 in several non-neuronal cells (Zhou et al., 1995; Kato et al., 1997, 1998; English et al., 1999; Kamakura et al., 1999). To determine whether MEK5 mediates BDNF stimulation of ERK5 in cortical neurons, MEK5 kinase activity was monitored by an immune complex kinase assay using GST-ERK5(M) as the substrate (Kato et al., 1997). BDNF activated MEK5 in cortical neurons, and like ERK5, MEK5 activation was maximal at $1 \mathrm{hr}$ and persisted for up to $24 \mathrm{hr}$ after BDNF stimulation (Fig. 4A).

To determine whether MEK5 is required for BDNF stimulation of ERK5, cortical neurons were transiently cotransfected with plasmid DNA encoding a Flag-tagged, wild-type ERK5 and a dominant-negative MEK5 or the MEK5 vector control (Fig. $4 B$ ). To determine the specificity of MEK5 for the ERK5 pathway, dominant-negative MEK5 was cotransfected with a Flagtagged, wild-type ERK2. Two days after transfection, neurons
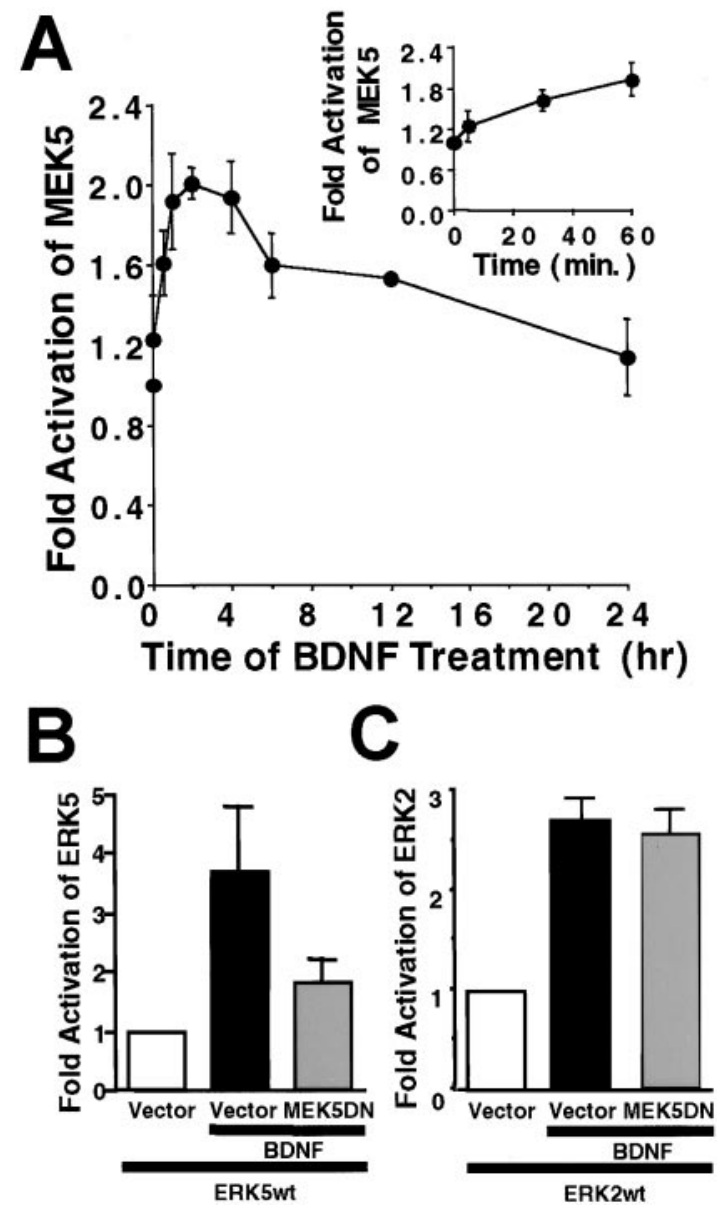

Figure 4. MEK5 is activated by BDNF and is required for BDNF stimulation of ERK5 in cortical neurons. $A$, Endogenous MEK5 is activated by BDNF. At DIV5, cortical neurons were treated with $10 \mathrm{ng} / \mathrm{ml}$ $\mathrm{BDNF}$ for various times. Three hundred micrograms of total protein were used for an MEK5 immune complex kinase assay with truncated GSTERK5(M) as the substrate. Inset, A more detailed profile of MEK5 activation at early time points is shown. Data shown are averages of two independent experiments. Error bars represent SEM. $B, C$, Expression of a dominant-negative MEK5 blocks BDNF stimulation of ERK5 $(B)$ but not ERK2 $(C)$. Cortical neurons (DIV3; $2 \times 10^{6}$ cells $/ 35 \mathrm{~mm}$ dish) were cotransfected with $2 \mu \mathrm{g}$ each of plasmid DNA encoding a wild-type Flag-tagged ERK5 (ERK5wt) or ERK2 (ERK2wt), a dominant-negative HA-tagged MEK5 (MEK5DN), or a vector control (pCMV5) as indicated. Two days later, cells were treated with $10 \mathrm{ng} / \mathrm{ml} \mathrm{BDNF}$ for $1 \mathrm{hr}$. Three hundred micrograms of total protein were used for immunoprecipitation with anti-Flag antibody. The transfected ERK5 and ERK2 kinase activities in the precipitates were assayed using GST-MEF2C or $\mathrm{MBP}$ as the respective substrates. Data shown are averages of three independent experiments. Error bars represent SEM.

were stimulated with $10 \mathrm{ng} / \mathrm{ml}$ BDNF for $1 \mathrm{hr}$. The activities of transfected ERK5 or ERK2 were determined by anti-Flag immune precipitation followed by an immune complex kinase assay using MEF2C or MBP as the substrate, respectively (Xia et al., 1995; Kato et al., 1997; Hetman et al., 1999). Similar to endogenous ERK5 and ERK2, the transfected wild-type ERK5 and ERK2 were activated by BDNF (Fig. 4B,C). Cotransfection of a dominant-negative MEK5, but not the vector control, inhibited BDNF stimulation of ERK5 (Fig. 4B). However, BDNF stimulation of ERK2 was not inhibited by this dominant-negative MEK5 (Fig. 4C). These data suggest that MEK5 is an upstream kinase that mediates BDNF activation of ERK5. 
Figure 5. cAMP, $\mathrm{KCl}$, and glutamate activate ERK1/2 but not ERK5 in cortical neurons. Cortical neurons (DIV5) were treated with vehicle control, $55 \mathrm{~mm} \mathrm{KCl}(A), 100 \mu \mathrm{M}$ glutamate $(B)$, or $2,5,10$, or $50 \mu \mathrm{M}$ forskolin $(C)$ that increases intracellular cAMP for the indicated times. For a positive control, neurons were treated with BDNF $(10 \mathrm{ng} / \mathrm{ml} ; 1$ hr). Phosphorylation $(p)$ of ERK5 and ERK1/2 was measured by Western analysis as described in Figure 1. Similar results were obtained in three independent experiments. Fsk, Forskolin.

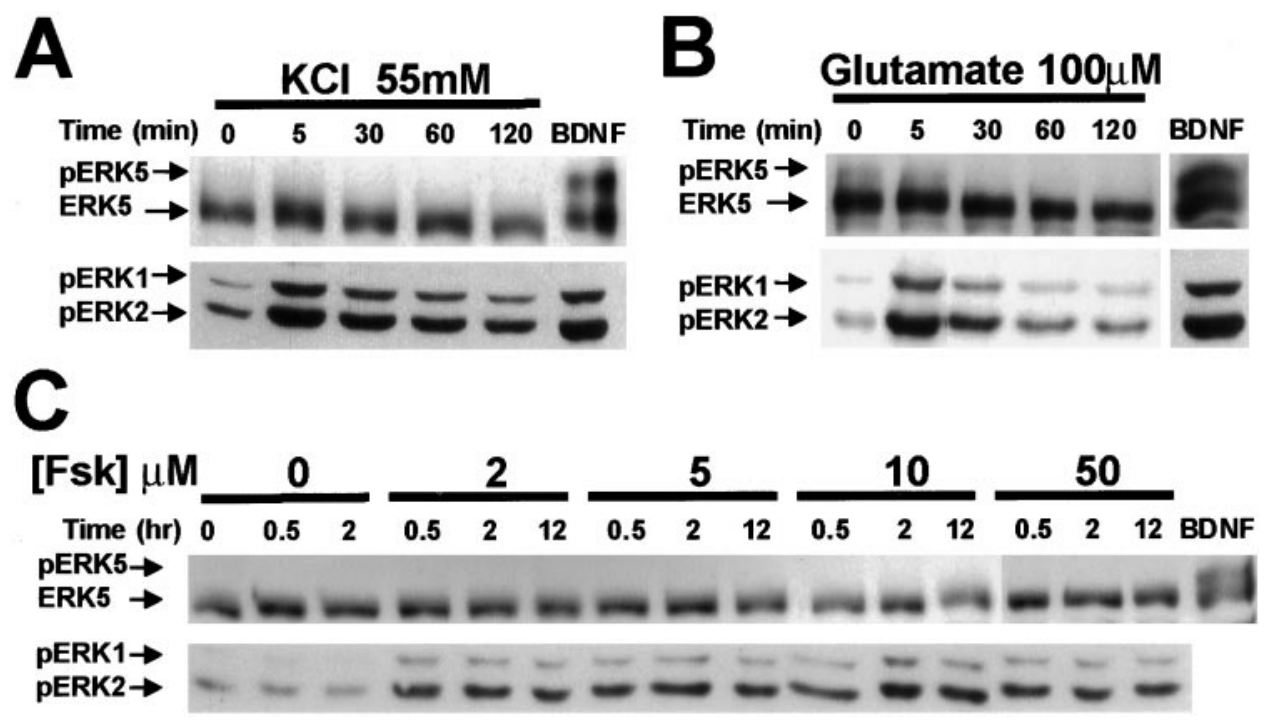

\section{Glutamate, membrane depolarization, and cAMP do not activate ERK5}

Because ERK1/2 activation by neuronal activity is critical for many aspects of neuronal function including neuronal survival (Curtis and Finkbeiner, 1999; Grewal et al., 1999) and neuronal plasticity (Siegelbaum and Kandel, 1991; Impey et al., 1999; Vanhoutte et al., 1999), it was important to determine whether ERK5 is also regulated by neuronal activity. Because ERK5 and ERK1/2 are both activated by neurotrophins, one might expect that ERK5, like ERK1/2, would also be activated by neuronal activity. To mimic neuronal activity in vitro, cultured neurons were treated with membrane-depolarizing concentrations of $\mathrm{KCl}(55 \mathrm{~mm})$ or with the excitatory neurotransmitter glutamate. Surprisingly, ERK5 was not stimulated by treatment with $55 \mathrm{~mm} \mathrm{KCl}$ for up to $2 \mathrm{hr}$ (Fig. $5 A$ ). Similarly, 30 or $100 \mu \mathrm{M}$ glutamate treatment for various times $(5-120$ min) did not activate ERK5 (Fig. 5B; data not shown). In contrast, both glutamate and membrane depolarization induced ERK1/2 phosphorylation (Fig. $5 A, B$ ), confirming that

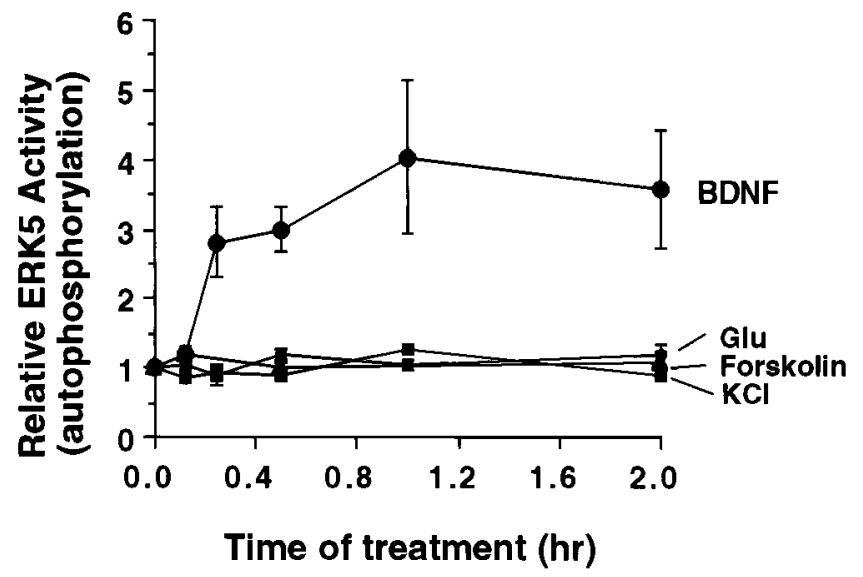

Figure 6. ERK5 autophosphorylation is not increased by $\mathrm{KCl}$, glutamate, or forskolin treatment of cortical neurons. Cortical neurons (DIV5DIV6) were treated with $10 \mathrm{ng} / \mathrm{ml} \mathrm{BDNF}, 55 \mathrm{~mm} \mathrm{KCl}, 30 \mu \mathrm{M}$ glutamate, or $2 \mu \mathrm{M}$ forskolin for various times. Three hundred micrograms of total protein were used to measure ERK5 activity by the autophosphorylation assay. Similar results were obtained with $50 \mu \mathrm{M}$ forskolin. Data shown are the averages of four to seven experiments. Error bars represent SEM. the cortical neurons used in the experiment showed normal responses to membrane depolarization and activation of glutamate receptors.

In neurons and PC12 cells, cAMP activates the ERK1/2 regulatory pathway. To determine whether ERK5 is also regulated by cAMP, cortical neurons were treated with forskolin, a general activator of adenylyl cyclases. Treatment of cortical neurons with 2-50 $\mu \mathrm{M}$ forskolin for 0.5, 2, or $12 \mathrm{hr}$ stimulated ERK1/2 (Fig. 5C), consistent with previous reports (Erhardt et al., 1995; Martin et al., 1997; Vossler et al., 1997; de Rooij et al., 1998; Kawasaki et al., 1998; Wei et al., 1998). However, under identical conditions, forskolin did not stimulate ERK5. We also quantitated ERK5 activity after glutamate, $\mathrm{KCl}$, or forskolin treatment using the ERK5 autophosphorylation assay (Fig. 6). In agreement with the results obtained using the phosphorylation shift assay, ERK5 was not activated after treatment with $30 \mu \mathrm{M}$ glutamate, $55 \mathrm{~mm} \mathrm{KCl}$, or $2 \mu \mathrm{M}$ forskolin (Fig. 6). These data indicate that ERK5 is stimulated by neurotrophins but not neuronal activity or cAMP.

\section{ERK5 and ERK1/2 regulate different downstream transcriptional pathways in PC12 cells and cortical neurons}

Although ERK5 and ERK1/2 activate some of the same transcription pathways in non-neuronal cells, there are differences in their downstream transcriptional targets. For example, they both phosphorylate transcription factors c-Myc and Sap1a (Kato et al., 1997; English et al., 1998; Yang et al., 1998; Kamakura et al., 1999; Marinissen et al., 1999). However, MEF2A and MEF2C are phosphorylated and activated by ERK5 but not by ERK1/2, whereas Elk1 is phosphorylated and activated by ERK1/2 but not by ERK5 (Gille et al., 1992; Janknecht et al., 1993; Marais et al., 1993; Kato et al., 1997; English et al., 1998; Yang et al., 1998; Marinissen et al., 1999). To determine whether ERK5 and ERK1/2 activate distinct transcriptional pathways in neurons, we examined the effect of ERK5 and ERK1/2 activation on transcription mediated by transcription factors MEF2C and Elk1 and on transcription initiated from the CRE using PC12 cells and cortical neurons. These transcription events were analyzed because MEF2C and CREB have been implicated in neuronal survival (Bonni et al., 1999; Mao et al., 1999; Riccio et al., 1999). Furthermore, the Elk1 and the CREB/CRE transcription pathways are 

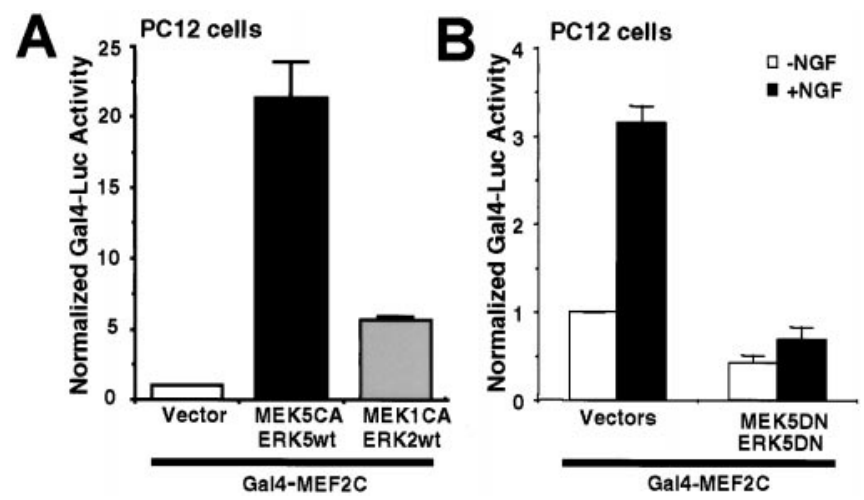

Figure 7. MEF2C-transactivating activity is stimulated by NGF and ERK5 in PC12 cells. PC12 cells were transfected with a Gal4-luciferase reporter gene $(0.2 \mu \mathrm{g} / 3$ wells $)$ and an expression vector for Gal4-MEF2C fusion protein $(0.4 \mu \mathrm{g} / 3$ wells $)$ to measure MEF2C transcriptional activity. An EF promoter-driven LacZ expression vector was cotransfected in all cases to normalize for transfection efficiency. $A, \mathrm{MEF} 2 \mathrm{C}$-mediated transactivation is preferentially stimulated by constitutive activation of the ERK5 pathway. To activate ERK5 or ERK1/2, cells were cotransfected with expression vectors $(0.1 \mu \mathrm{g}$ each $/ 3$ wells $)$ encoding a constitutively active MEK5 (MEK5CA) with a wild-type ERK5 (ERK5wt) or a $M E K 1 C A$ with an ERK2wt, respectively. Data shown are the averages of 12 independent experiments \pm SEM. $B$, MEF2C-mediated transcription is activated by NGF via an ERK5-dependent mechanism. To block ERK5 signaling, PC12 cells were transiently transfected with a dominantnegative MEK5 $(0.9 \mu \mathrm{g} / 4$ wells; $M E K 5 D N)$ together with a dominantnegative ERK5 $(0.9 \mu \mathrm{g} / 4$ wells; $E R K 5 D N)$ or the corresponding vector controls. Cells were treated with $50 \mathrm{ng} / \mathrm{ml} \mathrm{NGF}(+N G F)$ or vehicle control $(-N G F)$ for $6 \mathrm{hr}$. Data shown are the averages of three independent experiments \pm SEM. Luc, Luciferase.
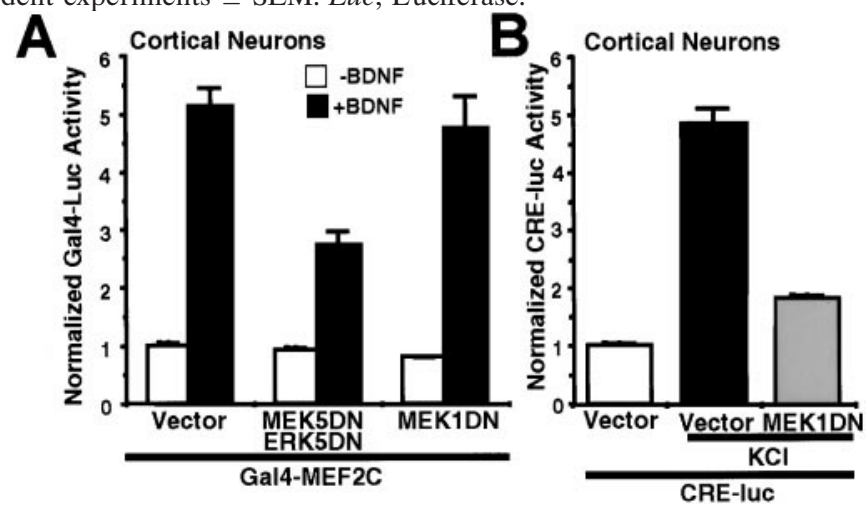

Figure 8. BDNF activates $\mathrm{MEF} 2 \mathrm{C}$ in cortical neurons that require ERK5 signaling. A, MEF2C-mediated transcription is activated by BDNF via an ERK5-dependent mechanism. Cortical neurons (DIV4DIV5; $0.5 \times 10^{6}$ cells/well) were transiently transfected with a Gal4luciferase reporter gene $(1.4 \mu \mathrm{g} / 4$ wells $)$ and an expression vector for Gal4-MEF2C fusion protein $(0.9 \mu \mathrm{g} / 4$ wells $)$ to measure MEF2C transcriptional activity. To block ERK5 or ERK1/2 signaling, neurons were cotransfected with a dominant-negative MEK5 (0.9 $\mu \mathrm{g} / 4$ wells; $M E K 5 D N)$ together with a dominant-negative ERK5 $(0.9 \mu \mathrm{g} / 4$ wells; $E R K 5 D N)$ or with a dominant-negative MEK1 (1.8 $\mu \mathrm{g} / 4$ wells; $M E K 1 D N)$, respectively. The corresponding vectors were used as controls. Cells were treated with $10 \mathrm{ng} / \mathrm{ml} \mathrm{BDNF}(+B D N F)$ or vehicle control $(-B D N F)$ for $6 \mathrm{hr}$. Data are representative of quadruplicate determinations from three independent experiments. $B$, KCl-activated CRE transcription is inhibited by the dominant-negative MEK1 used in $A$. To confirm that the $M E K 1 D N$ used in $A$ functioned properly as a dominant negative, cortical neurons were cotransfected with a CREluciferase reporter ( $2.4 \mu \mathrm{g} / 4$ wells), a $M E K 1 D N$, or its vector control (1.8 $\mu \mathrm{g} / 4$ wells). Cells were treated with $55 \mathrm{~mm} \mathrm{KCl}$ for $6 \mathrm{hr}$. Data shown are the averages of quadruplicate determinations. For both $A$ and $B$, an EF promoter-driven LacZ expression vector $(0.55 \mu \mathrm{g} / 4$ wells) was cotransfected to normalize for transfection efficiency, and error bars indicate SEM. Luc, Luciferase.
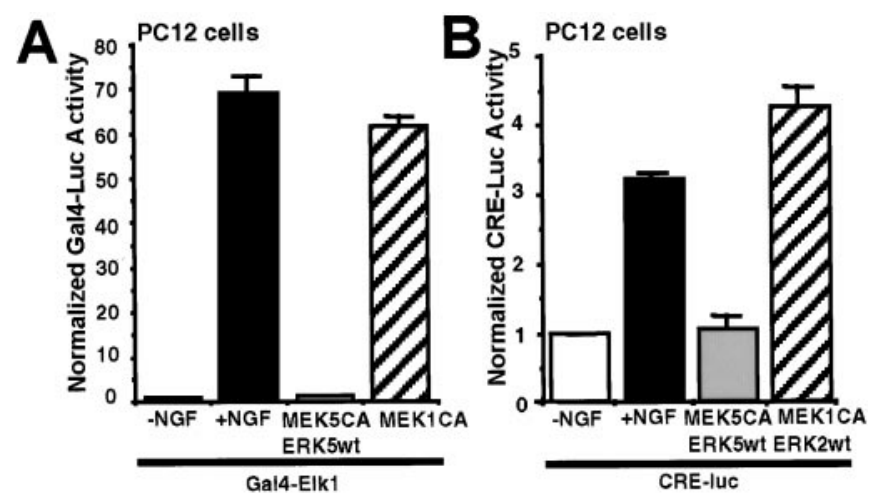

Figure 9. ERK5 does not stimulate Gal4-Elk1 transactivation or CREmediated transcription in PC12 cells. $A$, Transactivation of Elk1 is increased after NGF treatment or stimulation of the ERK1/2 but not the ERK5 pathway. PC12 cells were transfected with a Gal4-luciferase reporter gene $(0.2 \mu \mathrm{g} / 3$ wells $)$ and an expression vector for the Gal4-Elk1 fusion protein $(0.4 \mu \mathrm{g} / 3$ wells). To activate ERK5 or ERK1/2, cells were cotransfected with expression vectors encoding a constitutively active MEK5 $(0.2 \mu \mathrm{g} / 3$ wells; MEK5CA $)$ with a wild-type ERK5 $(0.6 \mu \mathrm{g} / 3$ wells; $E R K 5 w t)$ or a MEK1CA $(0.6 \mu \mathrm{g} / 3$ wells $)$, respectively. $B$, NGF treatment or constitutive activation of ERK1/2, but not ERK5, stimulates CREmediated transcription. PC12 cells were transfected with a CRE-luciferase reporter $(1.2 \mu \mathrm{g} / 3$ wells) to measure transcription initiated from CRE. To activate ERK5 or ERK1/2, cells were cotransfected with expression vectors encoding $M E K 5 C A(0.1 \mu \mathrm{g} / 3$ wells $)$ and $E R K 5 w t(0.3 \mu \mathrm{g} / 3$ wells) or $M E K 1 C A(0.1 \mu \mathrm{g} / 3$ wells $)$ and $E R K 2 w t(0.3 \mu \mathrm{g} / 3$ wells $)$, respectively. An EF promoter-driven LacZ expression vector was cotransfected in all cases to normalize for transfection efficiency. When indicated, cells were treated with NGF $(50 \mathrm{ng} / \mathrm{ml})$ for $6 \mathrm{hr}$. Data shown are the averages of triplicate determinations \pm SEM. Similar results were obtained in three to four independent experiments. $L u c$, Luciferase.

thought to contribute to memory formation (Berman et al., 1998; Impey et al., 1998b, 1999; Sgambato et al., 1998).

PC12 cells were transiently transfected with a constitutively active MEK5 and a wild-type ERK5 or a constitutively active MEK1 and a wild-type ERK2 to activate ERK5 or ERK1/2 signaling specifically. Activation of the ERK5- or ERK1/2signaling pathway caused 22 -fold and 5 -fold increases in Gal4$\mathrm{MEF} 2 \mathrm{C}$-mediated transcription, respectively, indicating that MEF2C transcription is preferentially activated by ERK5 (Fig. $7 A$ ). This is consistent with previous reports (Kato et al., 1997, 2000; English et al., 1998; Yang et al., 1998; Marinissen et al., 1999).

It has been reported that $\mathrm{MEF} 2 \mathrm{C}$ transcription is stimulated by membrane depolarization in cerebellar neurons (Mao and Wiedmann, 1999; Mao et al., 1999). However, it is not known whether neurotrophins stimulate MEF2C transcription in neurons. To address this issue, $\mathrm{PC} 12$ cells and cortical neurons were transiently transfected with a Gal4-MEF2C expression vector and a Gal4-luciferase reporter gene and treated with NGF or BDNF, respectively (Figs. $7 B, 8 A$ ). NGF and BDNF both activated Gal4-MEF2C-induced transcription, suggesting that $\mathrm{MEF} 2 \mathrm{C}$ transcription is also regulated by neurotrophins in neurons. Neurotrophins activate several kinase pathways in addition to ERK5 including the p38 MAP kinase pathway (Xing et al., 1998) that can also stimulate MEF2C transcription (Han et al., 1997). To determine the contribution of ERK5 signaling in neurotrophin stimulation of MEF2C transcription, we cotransfected PC12 cells and cortical neurons with a dominant-negative MEK5 together with a dominantnegative ERK5 to inhibit neurotrophin activation of the ERK5 
pathway. Expression of the dominant-negative MEK5 plus dominant-negative ERK5 inhibited MEF2C transcription induced by NGF and BDNF (Figs. 7B, 8A). To determine the specific involvement of the ERK5 pathway in neurotrophin stimulation of MEF2C transcription, we used a dominantnegative MEK1 as a negative control. Expression of this dominant-negative MEK1 construct blocked CRE-mediated transcription in cortical neurons after $\mathrm{KCl}$ stimulation (Fig. $8 B$ ), consistent with other reports (Impey et al., 1998a). However, it did not affect BDNF stimulation of MEF2C transcription (Fig. 8A). Together, these data suggest that MEF2C transcription is activated by neurotrophins via a mechanism involving the ERK5 but not the ERK1/2 pathway.

In contrast to MEF2C, Gal4-Elk1-induced transcription was enhanced by activation of ERK1/2 but not by ERK5 (Fig. 9A). Furthermore, unlike ERK1/2, ERK5 did not stimulate transcription from CRE (Fig. 9B). These data suggest that ERK5 and ERK1/2 activate distinct transcription pathways in PC12 cells and cortical neurons.

\section{DISCUSSION}

The objective of this study was to define the regulatory properties of ERK5 in primary cultures of cortical neurons in response to neurotrophins, neuronal activity, or cAMP. Neuronal activity was mimicked in vitro by treating cultured neurons with membrane-depolarizing concentrations of $\mathrm{KCl}$ or glutamate. The activity of endogenous ERK5 activity in cortical neurons was measured by two well established methods: the ERK5 autophosphorylation assay (Abe et al., 1997; Yan et al., 1999) and the reduced electrophoretic mobility assay (phosphorylation shift) (Kato et al., 1997, 1998). Neurotrophins including BDNF, NGF, NT-3, and NT-4 caused a sustained activation of MEK5 as well as ERK5 in PC12 cells and cortical neurons. BDNF activation of ERK5 was blocked by $\mathrm{K} 252 \mathrm{a}$, indicating a requirement for the receptor tyrosine kinase of TrkB. Furthermore, expression of a dominantnegative MEK5 blocked BDNF stimulation of ERK5, suggesting that MEK5 mediates neurotrophin stimulation of ERK5 in neurons.

Surprisingly, membrane depolarization, glutamate, or cAMP did not activate ERK5 in cortical neurons although they stimulated ERK1/2 activity. Furthermore, MEF2C was activated by neurotrophins, and the ERK5 signaling was required for neurotrophin stimulation of MEF2C transcription. On the other hand, ERK1/2, but not ERK5, activated Elk-1 transcriptional activity and stimulated transcription initiated from CRE. These data suggest that the regulatory properties of ERK5 as well as the downstream transcriptional pathways regulated by ERK5 are distinct from those of ERK1/2 in neurons.

Although neurotrophins activated both ERK5 and ERK1/2 pathways in cortical neurons, the kinetics of ERK5/MEK5 activation was slower than that of ERK1/2. One possibility for this difference is that the ERK5 and ERK1/2 pathways are activated by distinct upstream components, such as small G-proteins. For example, NGF activation of the ERK1/2 pathway in PC12 cells is both rapid and sustained. However, distinct mechanisms account for the two phases; the sustained activation of ERK1/2 by NGF requires the small G-protein Rap1, whereas the initial rapid activation requires Ras (York et al., 1998). It is possible that BDNF stimulation of the MEK5/ERK5 pathway is mediated by Rap1-like small G-proteins.
Because neuronal activity is critical for neuronal survival and synapse formation (Oppenheim, 1991; Bear and Malenka, 1994; Goldberg and Barres, 2000), it is important to elucidate mechanisms that translate activity changes to long-lasting modifications of neurons, particularly transcriptional changes. Activation of NMDA receptors or voltage-sensitive calcium channels increases intracellular $\mathrm{Ca}^{2+}$ and stimulates ERK1/2 in neuronal cells (Ely et al., 1990; Bading and Greenberg, 1991; Baraban et al., 1993; Fiore et al., 1993; Rosen et al., 1994; Kurino et al., 1995). ERK1/2 is also activated during LTP in mice and long-term facilitation in Aplysia (English and Sweatt, 1996; Martin et al., 1997; Impey et al., 1998b). Activitydependent activation of ERK1/2 has been implicated in several important aspects of CNS neuron function including LTP (Brambilla et al., 1997; English and Sweatt, 1997; Impey et al., 1998b, 1999) and memory formation (Atkins et al., 1998; Berman et al., 1998; Impey et al., 1999). Similar to ERK1/2, several other kinase-signaling pathways are stimulated by both neurotrophins and neuronal activity including those of the phosphatidylinositol-3 kinase, Akt, the c-Jun N-terminal protein kinase, and p38 MAP kinases (Farnsworth et al., 1995; Rusanescu et al., 1995; Tan et al., 1996; Kawasaki et al., 1997; Miller et al., 1997; Schwarzschild et al., 1997; Chen et al., 1998; Xing et al., 1998; Yano et al., 1998; Zhang et al., 1998; Grewal et al., 2000). Our data indicate that ERK5 is not activated by glutamate or membrane depolarization in cortical neurons, distinguishing this kinase from all of the other MAP kinases. ERK5 is the first MAP kinase identified that is activated by neurotrophins but not by neuronal activity.

Our observation that ERK5 in cortical neurons is not stimulated by $\mathrm{Ca}^{2+}$ is in accord with previous studies with nonneuronal cells showing that the $\mathrm{Ca}^{2+}$ ionophore A23187 does not activate ERK5 in COS7 and bovine aortic endothelial cells (BAEC) (Kamakura et al., 1999; Yan et al., 1999). However, the intracellular $\mathrm{Ca}^{2+}$ chelator BAPTA AM prevented ERK5 activation by EGF in mouse embryo fibroblasts and by shear stress in BAEC (Yan et al., 1999; Ji and Carpenter, 2000). This suggests that $\mathrm{Ca}^{2+}$ may be required, but is not sufficient, for ERK5 activation in non-neuronal cells.

cAMP inhibits growth factor stimulation of ERK1/2 in nonneuronal cells (Burgering et al., 1993; Graves et al., 1993) but stimulates ERK1/2 in neurons via Rap1 and B-raf (Erhardt et al., 1995; Vossler et al., 1997; de Rooij et al., 1998; Kawasaki et al., 1998). This emphasizes the importance of defining regulatory mechanisms for the MAP kinases in neurons because they are often different from those in non-neuronal cells. Activators of adenylyl cyclases markedly increase ERK1/2 activity in hippocampal neurons (Martin et al., 1997; Wei et al., 1998). Furthermore, activation of ERK1/2 by cAMP is critical for long-lasting LTP (English and Sweatt, 1996; Impey et al., 1998b). In contrast, our results suggest that ERK5 is not activated by increases in intracellular cAMP, which further distinguishes ERK5 from ERK1/2.

The MEF2 proteins constitute a family of transcription factors: MEF2A, MEF2B, MEF2C, and MEF2D. They cooperate with members of the MyoD family in muscle differentiation (Kaushal et al., 1994; Molkentin et al., 1995). In addition to muscle, MEF2A and MEF2C are also expressed in developing and adult brain including cortex and cerebellum (Leifer et al., 1993, 1994; McDermott et al., 1993; Lyons et al., 1995; Lin et al., 1996; Mao et al., 1999; Marinissen et al., 1999). Cortex contains a high level of MEF2C protein (Lin et al., 
1996). However, the function and regulation of MEF2 in the nervous system have not been extensively studied. Although MEF2 mediates $\mathrm{T}$ cell receptor-induced apoptosis in $\mathrm{T}$ cells (Youn et al., 1999), a recent study suggests that MEF2 mediates activity-dependent survival of cortical and cerebellar neurons (Mao et al., 1999). Although MEF2C transcription is stimulated by membrane depolarization in cerebellar neurons (Mao and Wiedmann, 1999; Mao et al., 1999), it has not been reported whether neurotrophins stimulate MEF2C transcription in neurons. Furthermore, the kinase-signaling mechanisms that mediate this transcription are unknown. Our data suggest that neurotrophins (NGF and BDNF) activate MEF2C transcription in both neuron-like PC12 cells and in primarycultured cortical neurons. Furthermore, ERK5 but not ERK1/2 signaling contributes to neurotrophin stimulation of MEF2C transcription.

The CREB/CRE transcriptional pathway is a major downstream target of ERK1/2 signaling that contributes to neuroplasticity (Impey et al., 1998b, 1999; Sgambato et al., 1998) and neuronal survival (Bonni et al., 1999; Riccio et al., 1999). Although CREB is not directly phosphorylated by ERK1/2, it is phosphorylated and transactivated by the ERK1/2-activated Rsk family of protein kinases p90 ${ }^{\text {rsk }}$ (Xing et al., 1996, 1998; Impey et al., 1998a). In addition to CREB, the transcription factor Elk1 may also be a major nuclear target of ERK1/2 important for synaptic plasticity (Berman et al., 1998; Sgambato et al., 1998). Elk1 is directly phosphorylated and activated by ERK1/2 (Gille et al., 1992, 1995; Janknecht et al., 1993; Marais et al., 1993) and plays an important role in NMDA-induced gene expression in neurons via serum response element (Xia et al., 1996). Our data suggest that ERK5 does not stimulate the transcriptional activity of Elk1 or transcription initiated from CRE. Together with the fact that ERK5 is not activated by neuronal activity, these results emphasize the importance of ERK1/2 signaling for activitydependent neural plasticity. Although ERK5 may not be directly stimulated by neuronal activity, it may be subsequently activated as a result of neurotrophin synthesis. For example, the promoter for BDNF contains a CRE element, and neuronal activity induces BDNF synthesis via the CREB/CRE transcriptional pathway (Shieh et al., 1998; Tao et al., 1998). BDNF expression is increased in brain during training for associative fear learning (Hall et al., 2000), a process that stimulates CRE-mediated transcription (Impey et al., 1998a) and is inhibited by MEK inhibitors (Atkins et al., 1998). Consequently, BDNF stimulation of ERK5 may contribute to synaptic plasticity and memory formation by stimulating other transcriptional pathways, e.g., MEF2Cmediated transcription.

In summary, our data identify several key differences between ERK5 and ERK1/2 in their response to neuronal activity and cAMP, as well as in downstream transcriptional targets. This suggests that ERK5 may have unique functions in the nervous system. For example, ERK5 may be particularly important for promoting neurotrophin-mediated neuronal survival during development when activity is not crucial for neuronal survival (Shatz, 1990; Oppenheim, 1991; Johnson and Deckwerth, 1993; Linden, 1994; Ikonomidou et al., 1999, 2000; Goldberg and Barres, 2000). It may also play a key role in neurotrophinpromoted survival when ERK1/2 expression is low during early development (Boulton et al., 1991) or in regions of the brain where ERK1/2 activity is low (Thomas and Hunt, 1993). Furthermore, the ERK5 survival mechanism may differ from and com- plement the ERK1/2 survival mechanism by activating distinct downstream transcriptional pathways.

\section{REFERENCES}

Abe J, Kusuhara M, Ulevitch RJ, Berk BC, Lee JD (1996) Big mitogenactivated protein kinase 1 (BMK1) is a redox-sensitive kinase. J Biol Chem 271:16586-16590.

Abe J, Takahashi M, Ishida M, Lee JD, Berk BC (1997) c-Src is required for oxidative stress-mediated activation of big mitogen-activated protein kinase 1 (BMK1). J Biol Chem 272:20389-20394.

Ahn NG, Seger R, Bratlien RL, Krebs EG (1992) Growth factorstimulated phosphorylation cascades: activation of growth factorstimulated MAP kinase. Ciba Found Symp 164:113-126; discussion $126-131$.

Anderson CNG, Tolkovsky AM (1999) A role for MAPK/ERK in sympathetic neuron survival: protection against a p53-dependent, JNKindependent induction of apoptosis by cytosine arabinoside. J Neurosci 19:664-673.

Atkins CM, Selcher JC, Petraitis JJ, Trzaskos JM, Sweatt JD (1998) The MAPK cascade is required for mammalian associative learning. Nat Neurosci 1:602-609.

Bading H, Greenberg ME (1991) Stimulation of protein tyrosine phosphorylation by NMDA receptor activation. Science 253:912-914.

Baraban JM, Fiore RS, Sanghera JS, Paddon HB, Pelech SL (1993) Identification of p42 mitogen-activated protein kinase as a tyrosine kinase substrate activated by maximal electroconvulsive shock in hippocampus. J Neurochem 60:330-336.

Bear MF, Malenka RC (1994) Synaptic plasticity: LTP and LTD. Curr Opin Neurobiol 4:389-399.

Berman DE, Hazvi S, Rosenblum K, Seger R, Dudai Y (1998) Specific and differential activation of mitogen-activated protein kinase cascades by unfamiliar taste in the insular cortex of the behaving rat. J Neurosci 18:10037-10044.

Bi R, Broutman G, Foy MR, Thompson RF, Baudry M (2000) The tyrosine kinase and mitogen-activated protein kinase pathways mediate multiple effects of estrogen in hippocampus. Proc Natl Acad Sci USA 97:3602-3607.

Bonni A, Brunet A, West AE, Datta SR, Takasu MA, Greenberg ME (1999) Cell survival promoted by the Ras-MAPK signaling pathway by transcription-dependent and -independent mechanisms [see comments]. Science 286:1358-1362.

Boulton TG, Nye SH, Robbins DJ, Ip NY, Radziejewska E, Morgenbesser SD, DePinho RA, Panayotatos N, Cobb MH, Yancopoulos GD (1991) ERKs: a family of protein-serine/threonine kinases that are activated and tyrosine phosphorylated in response to insulin and NGF. Cell 65:663-675.

Brambilla R, Gnesutta N, Minichiello L, White G, Roylance AJ, Herron CE, Ramsey M, Wolfer DP, Cestari V, RossiArnaud C, Grant SGN, Chapman PF, Lipp HP, Sturani E, Klein R (1997) A role for the Ras signalling pathway in synaptic transmission and long-term memory. Nature 390:281-286.

Burgering BM, Pronk GJ, van Weeren PC, Chardin P, Bos JL (1993) cAMP antagonizes p21ras-directed activation of extracellular signalregulated kinase 2 and phosphorylation of mSos nucleotide exchange factor. EMBO J 12:4211-4220.

Castellino AM, Chao MV (1996) Trans-signaling by cytokine and growth factor receptors. Cytokine Growth Factor Rev 7:297-302.

Chao TH, Hayashi M, Tapping RI, Kato Y, Lee JD (1999) MEKK3 directly regulates MEK5 activity as part of the big mitogen-activated protein kinase 1 (BMK1) signaling pathway. J Biol Chem 274:36035-36038.

Chen HJ, Rojas-Soto M, Oguni A, Kennedy MB (1998) A synaptic Ras-GTPase activating protein (p135 SynGAP) inhibited by CaM kinase II. Neuron 20:895-904.

Cherrington JM, Mocarski ES (1989) Human cytomegalovirus iel transactivates the alpha promoter-enhancer via an 18-base-pair repeat element. J Virol 63:1435-1440.

Chiariello M, Marinissen MJ, Gutkind JS (2000) Multiple mitogenactivated protein kinase signaling pathways connect the cot oncoprotein to the c-jun promoter and to cellular transformation. Mol Cell Biol 20:1747-1758.

Curtis J, Finkbeiner S (1999) Sending signals from the synapse to the nucleus: possible roles for CaMK, Ras/ERK, and SAPK pathways in the regulation of synaptic plasticity and neuronal growth. J Neurosci Res 58:88-95.

Dérijard B, Raingeaud J, Barrett T, Wu I-H, Han J, Ulevitch RJ, Davis RJ (1995) Independent human MAP kinase signal transduction pathways defined by MEK and MKK isoforms. Science 267:682-685.

de Rooij J, Zwartkruis FJ, Verheijen MH, Cool RH, Nijman SM, Wittinghofer A, Bos JL (1998) Epac is a Rap1 guanine-nucleotideexchange factor directly activated by cyclic AMP [see comments]. Nature 396:474-477.

Ely CM, Oddie KM, Litz JS, Rossomando AJ, Kanner SB, Sturgill TW, 
Parsons SJ (1990) A 42-kD tyrosine kinase substrate linked to chromaffin cell secretion exhibits an associated MAP kinase activity and is highly related to a $42-\mathrm{kD}$ mitogen-stimulated protein in fibroblasts. J Cell Biol 110:731-742.

English JD, Sweatt JD (1996) Activation of p42 MAP kinase in hippocampal long term potentiation. J Biol Chem 271:24329-24332.

English JD, Sweatt JD (1997) A requirement for the mitogen-activated protein kinase cascade in hippocampal long term potentiation. J Biol Chem 272:19103-19106.

English JM, Vanderbilt CA, Xu S, Marcus S, Cobb MH (1995) Isolation of MEK5 and differential expression of alternatively spliced forms. J Biol Chem 270:28897-28902.

English JM, Pearson G, Baer R, Cobb MH (1998) Identification of substrates and regulators of mitogen-activated protein kinase ERK5 using chimeric protein kinases. J Biol Chem 273:3854-3860.

English JM, Pearson G, Hockenberry T, Shivakumar L, White MA, Cobb MH (1999) Contribution of the ERK5/MEK5 pathway to Ras/Raf signaling and growth control. J Biol Chem 274:31588-31592.

Erhardt P, Troppmair J, Rapp UR, Cooper GM (1995) Differential regulation of Raf-1 and B-Raf and Ras-dependent activation of mitogen-activated protein kinase by cyclic AMP in PC12 cells. Mol Cell Biol 15:5524-5530.

Farnsworth CL, Freshney NW, Rosen LB, Ghosh A, Greenberg ME, Feig LA (1995) Calcium activation of Ras mediated by neuronal exchange factor Ras-GRF. Nature 376:524-527.

Fiore RS, Murphy TH, Sanghera JS, Pelech SL, Baraban JM (1993) Activation of p42 mitogen-activated protein kinase by glutamate receptor stimulation in rat primary cortical cultures. $\mathrm{J}$ Neurochem 61:1626-1633.

Gille R, Sharrocks AD, Shaw PE (1992) Phosphorylation of transcription factor $\mathrm{p} 62^{\mathrm{TCF}}$ by MAP kinase stimulates ternary complex formation at the c-fos promoter. Nature 358:414-417.

Gille R, Kortenjann M, Thomae O, Moomaw C, Slaughter C, Cobb MH, Shaw PE (1995) ERK phosphorylation potentiates Elk-1-mediated ternary complex formation and transactivation. EMBO J 14:951-962.

Goldberg JL, Barres BA (2000) The relationship between neuronal survival and regeneration. Annu Rev Neurosci 23:579-612.

Graves LM, Bornfeldt KE, Raines EW, Potts BC, Macdonald SG, Ross R, Krebs EG (1993) Protein kinase A antagonizes platelet-derived growth factor-induced signaling by mitogen-activated protein kinase in human arterial smooth muscle cells. Proc Natl Acad Sci USA 90:10300-10304

Grewal SS, York RD, Stork PJ (1999) Extracellular-signal-regulated kinase signalling in neurons. Curr Opin Neurobiol 9:544-553.

Grewal SS, Horgan AM, York RD, Withers GS, Banker GA, Stork PJ (2000) Neuronal calcium activates a Rap1 and B-Raf signaling pathway via the cyclic adenosine monophosphate-dependent protein kinase. J Biol Chem 275:3722-3728.

Hall J, Thomas KL, Everitt BJ (2000) Rapid and selective induction of BDNF expression in the hippocampus during contextual learning. Nat Neurosci 3:533-535.

Han J, Jiang Y, Li Z, Kravchenko VV, Ulevitch RJ (1997) Activation of the transcription factor MEF2C by the MAP kinase p38 in inflammation. Nature 386:296-299.

Hetman M, Kanning K, Cavanaugh JE, Xia Z (1999) Neuroprotection by brain-derived neurotrophic factor is mediated by extracellularsignal-regulated kinase and phosphatidylinositol-3 kinase. J Biol Chem $274: 22569-22580$

Hetman M, Cavanaugh JE, Kimelman D, Xia Z (2000) Role of glycogen synthase kinase- $3 \beta$ in neuronal apoptosis induced by trophic withdrawal. J Neurosci 20:2567-2574.

Ikonomidou C, Bosch F, Miksa M, Bittigau P, Vockler J, Dikranian K, Tenkova TI, Stefovska V, Turski L, Olney JW (1999) Blockade of NMDA receptors and apoptotic neurodegeneration in the developing brain. Science 283:70-74

Ikonomidou C, Bittigau P, Ishimaru MJ, Wozniak DF, Koch C, Genz K, Price MT, Stefovska V, Horster F, Tenkova T, Dikranian K, Olney JW (2000) Ethanol-induced apoptotic neurodegeneration and fetal alcohol syndrome [see comments]. Science 287:1056-1060.

Impey S, Mark M, Villacres EC, Poser S, Chavkin C, Storm DR (1996) Induction of CRE-mediated gene expression by stimuli that generate long-lasting LTP in area CA1 of the hippocampus. Neuron 16:973-982.

Impey S, Obrietan K, Wong ST, Poser S, Yano S, Wayman G, Deloulme JC, Chan G, Storm DR (1998a) Crosstalk between ERK and PKA is required for $\mathrm{Ca}^{2+}$ stimulation of CREB-dependent transcription and ERK nuclear translocation. Neuron 21:869-883.

Impey S, Smith DM, Obrietan K, Donahue R, Wade C, Storm DR (1998b) Stimulation of cAMP response element (CRE)-mediated transcription during contextual learning [see comments]. Nat Neurosci 1:595-601.

Impey S, Obrietan K, Storm DR (1999) Making new connections: role of ERK/MAP kinase signaling in neuronal plasticity. Neuron 23:11-14.

Janknecht R, Ernst WH, Pingoud V, Nordheim A (1993) Activation of ternary complex factor Elk-1 by MAP kinase. EMBO J 12:5097-5104.
Ji QS, Carpenter G (2000) Role of basal calcium in the EGF activation of MAP kinases. Oncogene 19:1853-1856.

Johnson Jr EM, Deckwerth TL (1993) Molecular mechanisms of developmental neuronal death. Annu Rev Neurosci 16:31-46.

Kamakura S, Moriguchi T, Nishida E (1999) Activation of the protein kinase ERK5/BMK1 by receptor tyrosine kinases. Identification and characterization of a signaling pathway to the nucleus. J Biol Chem 274:26563-26571.

Kato Y, Kravchenko VV, Tapping RI, Han JH, Ulevitch RJ, Lee JD (1997) BMK1/ERK5 regulates serum-induced early gene expression through transcription factor MEF2C. EMBO J 16:7054-7066.

Kato Y, Tapping RI, Huang S, Watson MH, Ulevitch RJ, Lee JD (1998) Bmk1/Erk5 is required for cell proliferation induced by epidermal growth factor. Nature 395:713-716.

Kato Y, Zhao M, Morikawa A, Sugiyama T, Chakravortty D, Koide N, Yoshida T, Tapping RI, Yang Y, Yokochi T, Lee JD (2000) Big mitogen-activated kinase regulates multiple members of the MEF2 protein family. J Biol Chem 275:18534-18540.

Kaushal S, Schneider JW, Nadal-Ginard B, Mahdavi V (1994) Activation of the myogenic lineage by MEF2A, a factor that induces and cooperates with MyoD. Science 266:1236-1240.

Kawasaki H, Morooka T, Shimohama S, Kimura J, Hirano T, Gotoh Y, Nishida E (1997) Activation and involvement of p38 mitogenactivated protein kinase in glutamate-induced apoptosis in rat cerebellar granule cells. J Biol Chem 272:18518-18521.

Kawasaki H, Springett GM, Mochizuki N, Toki S, Nakaya M, Matsuda M, Housman DE, Graybiel AM (1998) A family of cAMP-binding proteins that directly activate Rap1. Science 282:2275-2279.

Kurino M, Fukunaga K, Ushio Y, Miyamoto E (1995) Activation of mitogen-activated protein kinase in cultured rat hippocampal neurons by stimulation of glutamate receptors. J Neurochem 65:1282-1289.

Lee JD, Ulevitch RJ, Han J (1995) Primary structure of BMK1: a new mammalian map kinase. Biochem Biophys Res Commun 213:715-724.

Leifer D, Krainc D, Yu YT, McDermott J, Breitbart RE, Heng J, Neve RL, Kosofsky B, Nadal-Ginard B, Lipton SA (1993) MEF2C, a MADS/MEF2-family transcription factor expressed in a laminar distribution in cerebral cortex. Proc Natl Acad Sci USA 90:1546-1550.

Leifer D, Golden J, Kowall NW (1994) Myocyte-specific enhancer binding factor $2 \mathrm{C}$ expression in human brain development. Neuroscience 63:1067-1079.

Lin X, Shah S, Bulleit RF (1996) The expression of MEF2 genes is implicated in CNS neuronal differentiation. Mol Brain Res 42:307-316.

Linden R (1994) The survival of developing neurons: a review of afferent control. Neuroscience 58:671-682.

Lyons GE, Micales BK, Schwarz J, Martin JF, Olson EN (1995) Expression of mef2 genes in the mouse central nervous system suggests a role in neuronal maturation. J Neurosci 15:5727-5738.

Mansour SJ, Matten WT, Hermann AS, Candia JM, Rong S, Fukasawa K, Vande Woude GF, Ahn NG (1994) Transformation of mammalian cells by constitutively active MAP kinase kinase. Science 265:966-970.

Mao Z, Wiedmann M (1999) Calcineurin enhances MEF2 DNA binding activity in calcium-dependent survival of cerebellar granule neurons. J Biol Chem 274:31102-31107.

Mao Z, Bonni A, Xia F, Nadal-Vicens M, Greenberg ME (1999) Neuronal activity-dependent cell survival mediated by transcription factor MEF2. Science 286:785-790.

Marais R, Wynne J, Treisman R (1993) The SRF accessory protein Elk-1 contains a growth factor-regulated transcriptional activation domain. Cell 73:381-393.

Marinissen MJ, Chiariello M, Pallante M, Gutkind JS (1999) A network of mitogen-activated protein kinases links $\mathrm{G}$ protein-coupled receptors to the c-jun promoter: a role for c-Jun NH2-terminal kinase, p38s, and extracellular signal-regulated kinase 5. Mol Cell Biol 19:4289-4301.

Marsh HN, Scholz WK, Lamballe F, Klein R, Nanduri V, Barbacid M, Palfrey HC (1993) Signal transduction events mediated by the BDNF receptor gp 145 trkB in primary hippocampal pyramidal cell culture. J Neurosci 13:4281-4292.

Martin KC, Michael D, Rose JC, Barad M, Casadio A, Zhu HX, Kandel ER (1997) MAP kinase translocates into the nucleus of the presynaptic cell and is required for long-term facilitation in Aplysia. Neuron 18:899-912.

Matthews RP, Guthrie CR, Wailes LM, Zhao X, Means AR, McKnight GS (1994) Calcium/calmodulin-dependent protein kinase types II and IV differentially regulate CREB-dependent gene expression. Mol Cell Biol 14:6107-6116.

McDermott JC, Cardoso MC, Yu YT, Andres V, Leifer D, Krainc D, Lipton SA, Nadal-Ginard B (1993) hMEF2C gene encodes skeletal muscle- and brain-specific transcription factors. Mol Cell Biol 13:2564-2577.

MeyerFranke A, Wilkinson GA, Kruttgen A, Hu M, Munro E, Hanson MG, Reichardt LF, Barres BA (1998) Depolarization and cAMP elevation rapidly recruit TrkB to the plasma membrane of CNS neurons. Neuron 21:681-693.

Miller TM, Tansey MG, Johnson EM, Creedon DJ (1997) Inhibition of phosphatidylinositol 3-kinase activity blocks depolarization- and 
insulin-like growth factor I-mediated survival of cerebellar granule cells. J Biol Chem 272:9847-9853.

Molkentin JD, Black BL, Martin JF, Olson EN (1995) Cooperative activation of muscle gene expression by MEF2 and myogenic bHLH proteins. Cell 83:1125-1136.

Montminy MR, Bilezikjian LM (1987) Binding of a nuclear protein to the cyclic-AMP response element of the somatostatin gene. Nature 328:175-178.

Oppenheim RW (1991) Cell death during development of the nervous system. Annu Rev Neurosci 14:453-501.

Poser S, Impey K, Trinh K, Xia Z, Storm DR (2000) SRF-dependent gene expression is required for mitogen-induced proliferation through a PI3 kinase signal transduction cascade. EMBO J 19:4955-4966.

Riccio A, Ahn S, Davenport CM, Blendy JA, Ginty DD (1999) Mediation by a CREB family transcription factor of NGF-dependent survival of sympathetic neurons. Science 286:2358-2361.

Rosen LB, Ginty DD, Weber MJ, Greenberg ME (1994) Membrane depolarization and calcium influx stimulate MEK and MAP kinase via activation of ras. Neuron 12:1207-1221.

Rusanescu G, Qi H, Thomas SM, Brugge JS, Halegous S (1995) Calcium influx induces neurite growth through a Src-Ras signaling cassette. Neuron 15:1415-1425.

Schwarzschild MA, Cole RL, Hyman SE (1997) Glutamate, but not dopamine, stimulates stress-activated protein kinase and AP-1mediated transcription in striatal neurons. J Neurosci 17:3455-3466.

Segal RA, Greenberg ME (1996) Intracellular signaling pathways activated by neurotrophic factors. Annu Rev Neurosci 19:463-489.

Sgambato V, Pages C, Rogard M, Besson MJ, Caboche J (1998) Extracellular signal-regulated kinase (ERK) controls immediate early gene induction on corticostriatal stimulation. J Neurosci 18:8814-8825.

Shatz CJ (1990) Impulse activity and the patterning of connections during CNS development. Neuron 5:745-756.

Shieh PB, Hu SC, Bobb K, Timmusk T, Ghosh A (1998) Identification of a signaling pathway involved in calcium regulation of BDNF expression. Neuron 20:727-740.

Siegelbaum SA, Kandel ER (1991) Learning-related synaptic plasticity: LTP and LTD. Curr Opinion Neurobiol 1:113-120.

Singer CA, Figueroa-Masot XA, Batchelor RH, Dorsa DM (1999) The mitogen-activated protein kinase pathway mediates estrogen neuroprotection after glutamate toxicity in primary cortical neurons. J Neurosci 19:2455-2463.

Skaper SD, Floreani M, Negro A, Facci L, Giusti P (1998) Neurotrophins rescue cerebellar granule neurons from oxidative stress-mediated apoptotic death: selective involvement of phosphatidylinositol 3-kinase and the mitogen-activated protein kinase pathway. J Neurochem 70:1859-1868.

Tan Y, Rouse J, Zhang AH, Cariati S, Cohen P, Comb MJ (1996) FGF and stress regulate CREB and ATF-1 via a pathway involving p38 MAP kinase and MAPKAP kinase-2. EMBO J 15:4629-4642.

Tao X, Finkbeiner S, Arnold DB, Shaywitz AJ, Greenberg ME (1998) $\mathrm{Ca}^{2+}$ influx regulates BDNF transcription by a CREB family transcription factor-dependent mechanism. Neuron [Erratum (1998) 20:1297] 20:709-726.

Thomas KL, Hunt SP (1993) The regional distribution of extracellularly regulated kinase- 1 and -2 messenger RNA in the adult rat central nervous system. Neuroscience 56:741-757.

Vanhoutte P, Barnier J-V, Guibert B, Pages C, Besson M-J, Hipskind
RA, Caboche J (1999) Glutamate induces phosphorylation of Elk-1 and CREB, along with c-fos activation, via an extracellular signalregulated kinase-dependent pathway in brain slices. Mol Cell Biol 19:136-146.

Villalba M, Journot L (1997) Pituitary adenylate cyclase-activating polypeptide (PACAP-38) protects cerebellar granule neurons from apoptosis by activating the mitogen-activated protein kinase (MAP kinase) pathway. J Neurosci 17:83-90.

Vossler MR, Yao H, York RD, Pan MG, Rim CS, Stork PJS (1997) cAMP activates MAP kinase and Elk-1 through a B-Raf- and Rap1dependent pathway. Cell 89:73-82.

Wei J, Zhao AZ, Chan GC, Baker LP, Impey S, Beavo JA, Storm DR (1998) Phosphorylation and inhibition of olfactory adenylyl cyclase by CaM kinase II in neurons: a mechanism for attenuation of olfactory signals. Neuron 21:495-504.

Xia Z, Dickens M, Raingeaud J, Davis RJ, Greenberg ME (1995) Opposing effects of ERK and JNK-p38 MAP kinases on apoptosis. Science 270:1326-1331.

Xia Z, Dudek H, Miranti CK, Greenberg ME (1996) Calcium influx via the NMDA receptor induces immediate early gene transcription by a MAP kinase/ERK-dependent mechanism. J Neurosci 16:5425-5436.

Xing J, Ginty DD, Greenberg ME (1996) Coupling of the Ras-MAPK pathway to gene activation by RSK2, a growth factor-regulated CREB kinase. Science 65:959-963.

Xing J, Kornhauser JM, Xia Z, Thiele EA, Greenberg ME (1998) Nerve growth factor activates extracellular signal-regulated kinase and p38 mitogen-activated protein kinase pathways to stimulate CREB serine 133 phosphorylation. Mol Cell Biol 18:1946-1955.

Yan C, Takahashi M, Okuda M, Lee JD, Berk BC (1999) Fluid shear stress stimulates big mitogen-activated protein kinase 1 (BMK1) activity in endothelial cells. Dependence on tyrosine kinases and intracellular calcium. J Biol Chem 274:143-150.

Yang CC, Ornatsky OI, McDermott JC, Cruz TF, Prody CA (1998) Interaction of myocyte enhancer factor 2 (MEF2) with a mitogenactivated protein kinase, ERK5/BMK1. Nucleic Acids Res 26:4771-4777.

Yano S, Tokumitsu H, Soderling TR (1998) Calcium promotes cell survival through CaM-K kinase activation of the protein-kinase-B pathway. Nature 396:584-587.

Yao H, York RD, Misra-Press A, Carr DW, Stork PJ (1998) The cyclic adenosine monophosphate-dependent protein kinase (PKA) is required for the sustained activation of mitogen-activated kinases and gene expression by nerve growth factor. J Biol Chem 273:8240-8247.

York RD, Yao H, Dillon T, Ellig CL, Eckert SP, McCleskey EW, Stork PJ (1998) Rap1 mediates sustained MAP kinase activation induced by nerve growth factor [see comments]. Nature 392:622-626.

Youn HD, Sun L, Prywes R, Liu JO (1999) Apoptosis of T cells mediated by $\mathrm{Ca}^{2+}$-induced release of the transcription factor MEF2. Science 286:790-793.

Zhang FX, Rubin R, Rooney TA (1998) N-Methyl-D-aspartate inhibits apoptosis through activation of phosphatidylinositol 3-kinase in cerebellar granule neurons. A role for insulin receptor substrate-1 in the neurotrophic action of $N$-methyl-D-aspartate and its inhibition by ethanol. J Biol Chem 273:26596-26602.

Zhou G, Bao ZQ, Dixon JE (1995) Components of a new human protein kinase signal transduction pathway. J Biol Chem 270:12665-12669. 